DE DE GRUYTER OPEN
ACTA ENVIRONMENTALICA

UNIVERSITATIS COMENIANAE (BRATISLAVA)

ISSN 1339-9802 (online)

\title{
HOW THE MANAGEMENT MAY AFFECT DISPERSAL OF SLENDER SPEEDWELL (VERONICA FILIFORMIS SMITH) IN MEADOWS AND PASTURES
}

\author{
Božena Šerá ${ }^{1} \&$ Milan Kobes ${ }^{1}$ \\ ${ }^{1}$ Department of Landscape Ecology, Faculty of Natural Sciences, Comenius University in Bratislava, Mlynská dolina, \\ Ilkovičova 6, 84215 Bratislava, Slovak Republic, e-mail: sera@fns.uniba.sk \\ ${ }^{2}$ Department of Plant Production and Agroecology, Faculty of Agriculture, University of South Bohemia, Studentská 13, \\ 37005 České Budějovice, e-mail: kobes@zf.jcu.cz
}

\begin{abstract}
Slender speedwell (Veronica filiformis Smith, family Plantaginaceae) is a non-native and invasive species of grassland in the Europe. The aim of the study was to test the ability of the growth and spreading in nine differently managed grasslands (mowing, mulching, grazing). The best survival was found in two-years mowed lots with fertilisation and in all lots with not permanent cattle pasture crops. There were found the highest number of survived plants and plants with big "rosette" diameters. Number of survived plant for two seasons was 18 and total number of vegetative peaks per plant was 688. The potential for the spreading of such plant population is great. On the other hand, plants did not survived in lots with mulch treatment and in fenced lots with permanent cattle grazing.
\end{abstract}

Key words: agricultural management, grazing, invasive plants, mesophilic grasslands, mowing

Recommended form of citation: Šerá, B. \& Kobes, M., 2016. How the management may affect dispersal of slender speedwell (Veronica filiformis smith) in meadows and pastures. Acta Environ. Univ. Comenianae (Bratislava). 24(2): XX$X X$.

DOI: 10.1515/aeuc-2016-0011

\section{INTRODUCTION}

Structure of grass cover can be influenced by invasive and expansive plant species. Mainly invasive species (PERGL et al. 2016) are in the centre of attention. Traits predetermining the ability to invade are neither easily nor unambiguously set. It is often the case that successful invasive plant species can show very opposing traits (PYŠEK 2001). The success can be supported by high production of seeds and fruits on one hand, and on the other hand by total absence of reproductive propagation, substituted with intense vegetative spread. Generally speaking, conditions for invasion are competition ability, fertility, seed germination, fast growth and a large production of biomass (PYŠEK 2001).

Growth and absence of generative reproduction are characteristic for Slender speedwell (Veronica filiformis Smith, family Plantaginaceae). This species comes from the western Caucasus, classified as 
domesticated neophyte in the Czech Republic (PYŠEK et al. 2012). Currently it is common in central, northern and north-western Europe (SCALONE \& ALBACH 2012), in North America (USDA, NRCS 2016) and New Zealand (WEBB et al. 1988).

Slender speedwell is a low dicotyledonous herbaceous plant with a procumbent stem, delicate round leaves and fine blue-white blossoms. Stems can root by adventive way in nodes, create other vegetative apexes, and thus enable quick vegetative regeneration (HARRIS \& LOWELL 1980a; ŠERÁ 2012). The plants have a low genetic variability created by a limited number of clones. The production of pollen and seeds is also low, seeds either have low germination, or they are not developed at all (SCALONE \& ALBACH 2012).

In our conditions Slender speedwell always preferred and prefers grasslands and mowing lawns (SOJÁK \& ŠOUREK 1959; JeHLÍK 1961, 1998; JEHLíK \& SLAVÍK 1967; PENIAŠTEKOVÁ \& ZLINSKÁ 1995; KAPLAN et al. 2016). It is ranked among synanthropic species spreading by planting or by swiping of agricultural and small municipal engineering (MÜLLER \& SUKOPP 1993). Particularly colder and wetter conditions suit him (HARRIS \& LOWELL 1980b; SCALONE \& ALBACH 2012).

Slender speedwell propagates mainly in grass covers, and is able to regenerate from vegetative parts. However, little is known about the influence of various types of management on the species propagation. This paper presents the results of an experiment focused on the influence of various frequency grass moving and grazing on mesophilic meadows and pastures with regard to the propagation possibilities of this species. We assume that the Slender speedwell will prosper only under the some type of the tested managements. This kind of management will be the "risk" for grassland, because it may encourage the spread of this invasive species.

\section{MATERIAL AND METHODS}

\section{Experimental location and lots}

The experiment was run on a grass location called Velký Chuchelec, which are experimental grounds of the Department of Plant Production and Agroecology, the Faculty of Agriculture at the University of South Bohemia in České Budějovice. The grounds are located at the foothills of the Šmava on the western part of the Kaplice basin. The climate has a highland character of moderate to lower humidity, slightly influenced by the rain shadow of the Šumava and the Alps. Average monthly temperatures and precipitation are shown in Table 1. Other characteristics: altitude of $650 \mathrm{~m}$ a. s. 1 ., slope of $11^{\circ}$, ESE exposure, soil deep cambisol, N 48 $45^{\prime} 26^{\prime \prime}$ E 1444'76").

The experimental grounds of Velký Chuchelec is divided into lots of $3 \times 10$ metres which are managed by mowing (harvesting), mulching and cattle grazing in the long-term run (Fig. 1).

Tab. 1: The average monthly air temperature and average monthly precipitation at the location Velký Chuchelec. Data come from the local university hydrometeorological station

\begin{tabular}{|c|c|c|c|c|c|c|c|c|c|c|c|c|c|c|}
\hline $\begin{array}{l}\text { Meteorological } \\
\text { characteristics }\end{array}$ & Year/month & I & II & III & IV & V & VI & VII & VIII & IX & $X$ & $X I$ & XII & Mean \\
\hline \multirow{3}{*}{$\begin{array}{c}\text { Temperature } \\
\left({ }^{\circ} \mathrm{C}\right)\end{array}$} & 2010 & -4.6 & -2.2 & +3.0 & +9.5 & +11.9 & +16.5 & +19.7 & +17.5 & +12.1 & +8.2 & +2.8 & -4.6 & +7.5 \\
\hline & 2011 & -1.4 & -0.9 & +4.5 & +9.8 & +14.1 & +16.8 & +16.5 & +17.7 & +14.4 & +7.1 & +3.1 & +1.1 & +8.5 \\
\hline & 2012 & -0.9 & -2.9 & +4.4 & +7.7 & +12.8 & +16.0 & +17.3 & +18.1 & +14.1 & +7.5 & +3.1 & -0.7 & +8.0 \\
\hline \multirow{3}{*}{$\begin{array}{l}\text { Precipitation } \\
\qquad(\mathrm{mm})\end{array}$} & 2010 & 30.0 & 26.5 & 29.5 & 45.8 & 118.6 & 106.3 & 171.6 & 111.6 & 49.9 & 17.4 & 28.0 & 29.4 & 764.6 \\
\hline & 2011 & 33.7 & 10.6 & 47.9 & 26.5 & 116.3 & 65.2 & 114.6 & 50.0 & 94.9 & 62.4 & 0.0 & 39.2 & 661.3 \\
\hline & 2012 & 54.4 & 19.5 & 11.3 & 58.5 & 67.2 & 125.2 & 160.2 & 101.6 & 80.6 & 39.4 & 22.4 & 56.5 & 797.2 \\
\hline
\end{tabular}




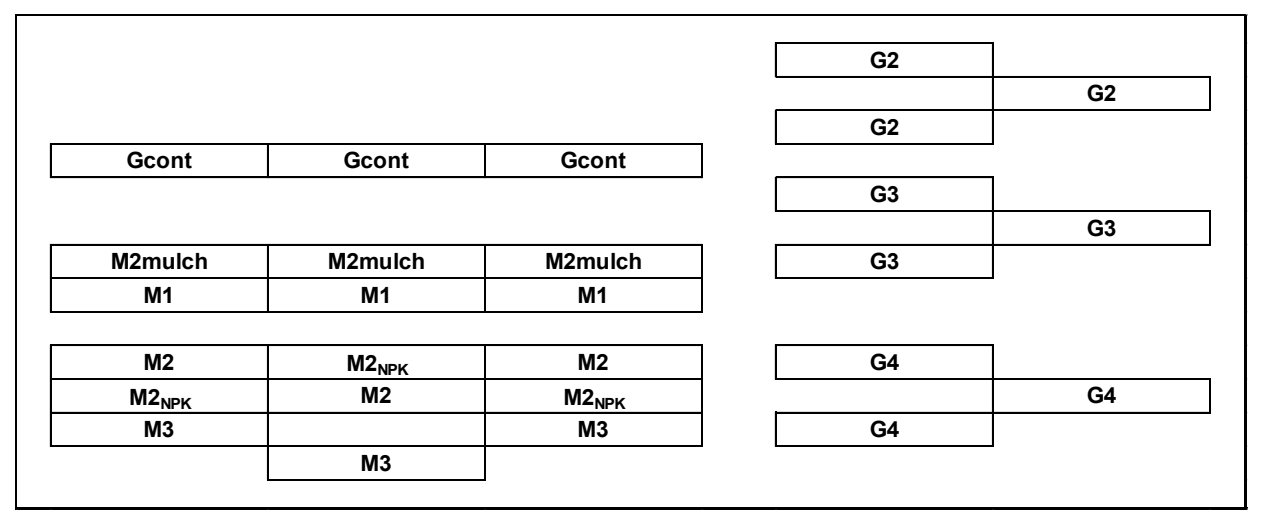

Fig. 1: Spatial distribution of plots $(3 \times 10 \mathrm{~m})$ in the location Velký Chuchelec in 2010 - 2012. Experimental treatments are marked according to: M1 - 1 one-mowing per a year, M2 - two mowings per a year, M3 - three mowings per a year, M2NPK - two mowings and a fertilisation per a year, M2mulch - two mowings and mulch per a year, G2 - two grazings per a year, G3 - three grazings per a year, G4 - four grazings per a year, Gcont - continual grazing.

\section{Long-term management (mowing, mulching, grazing)}

Experimental mowing lots are cut from 1 to 3 times a year with an MF-70 grass cutter, the length of grass set to $4-5 \mathrm{~cm}$. The harvested biomass is immediately removed. A Vari-Tajfun mulcher is used in case of mulching management, combined mulching and mowing, or mulching and grazing option. The mulch is kept on the location. One of the two-harvest lots in manually fertilized with NPK fertilizers, in the annual amount of $100 \mathrm{~kg} \mathrm{~N}, 30 \mathrm{~kg} \mathrm{P}$ and $50 \mathrm{~kg} \mathrm{~K}$ per 1 ha (fertilizers: ammonium nitrate with lime $27.5 \% \mathrm{~N}$, granulated triple superphosphate $45 \% \mathrm{P}_{2} \mathrm{O}_{5}$ and potassium nitrate $60 \%$ $\mathrm{K}_{2} \mathrm{O}$ ). A doze of nitrogen was applied separately $70 \mathrm{~kg} \mathrm{~N}$ per 1 ha in the spring and $30 \mathrm{~kg}$ after the first harvest. Fenced grazing is 2-4 times a year, and/or continuous grazing. The cattle herd consisted of two breeds, Charolais and Simental. Further details on the lot management are in KoBES et al. (2013).

Our experiment was run during 2010 - 2012 on experimental lots having three basic managements (mowing, mulching, grazing) with more options. We had 9 management options (all together) and each management option in three repetitions (see Fig. 1):

Mowing (M): M1 - 1 one-mowing per a year, M2 - two mowings per a year, M3 - three mowings per a year, M2NPK - two mowings and a fertilisation per a year,

Mulching (Mmulch): M2mulch - two mowings and mulch per a year,

Grazing (G): G2 - two grazings per a year, G3 - three grazings per a year, G4 - four grazings per a year, Gcont - continual grazing.

\section{Plant material}

The source of the plant material was a population of Slender speedwell (Veronica filiformis) taken in the spring of 2009 from the region of Velké Skaliny (foothills of the Novohradské hory Mountains, $\mathrm{N} 48^{\circ} 44^{\prime} 49.2^{\prime \prime}$ E $\left.14^{\circ} 34^{\prime} 43.4^{\prime \prime}\right)$. Individual plants were generated vegetatively from that material and grown in separate pots $(3 \times 3 \times 6 \mathrm{~cm})$, using a standard substrate (AGRO with active humus). 270 healthy plants of minimum stem length $4.5 \mathrm{~cm}$ were used in the experiment.

\section{Slender speedwell growing}

The plants were planted in the lots (see above, Fig. 1) managed in various ways in the spring of 2010 in a way avoiding a marginal effect and potential inner-species influences (at minimum $0.5 \mathrm{~m}$ distance). 10 plants were used on each lot, 3 lots for each type of management (30 plants per one 
treatment). After the plants rooted, standard management continued.

During vegetation, the following aspects were measured 2-3 times a year: number of living individuals, diameter of the "rosette" (maximum length of the plant laid on the ground) and a total number of apexes on the plant. The length of the plants at the beginning of the experiment was used as the basis $(100 \%)$ for evaluation of growth characteristics ("rosette" diameter). Growth development and differences in growth characteristics among lots with different management were evaluated using MS Excel.

\section{RESULTS}

Majority of speedwell creeping plants survived the first winter on all lots, regardless the type of management (Figs. 2, 3). After two years of management, the numbers of plants started to differ. The biggest number of plants survived on grazed lots (except for permanently grazed lots) and on twoharvest lots with fertilizing (Fig. 2). On the other hand, a quick and big mortality was recorded on mulched lots, one-harvest lots, and lots under permanent grazing. Slender speedwell disappeared on those lots totally (Fig. 3).

Concerning the diameter of the "rosette", the fastest growing plants were on two and threeharvested lots (130\% and 120\%), on harvested lots with fertilizing (116\%) and on 4-times-a-year in fenced grazing (112\%) (Figs. 4, 5). The smallest expansion shortly after planting was recorded on mulched lots (30\%) and on lots with permanent grazing (55\%) (Figs. 4, 5).

At the end of the experiment, the biggest diameters were recorded on two-harvest lots with fertilizing (62\%) and on 4-times-a-year in fenced grazing (59\%) (Figs. 4, 5). Slender speedwell survived on two-harvested lots but the plants were small and had the smallest diameters of "rosette" (5\%) (Fig. 4).

In total, 18 plants out of 270 survived (Table 2). The biggest individuals were plants with the "rosette" diameter of $1.01 \mathrm{~m}$ and 156 terminals (fenced grazing 4 times a year), diameter of $0.87 \mathrm{~m}$ and 155 terminals (grazing 2 times a year), and a plant with an diameter of $0.67 \mathrm{~m}$ and 131 terminals (fenced grazing 3 times a year). The most successful lots were harvested lots with fertilizing and in fenced grazing 4 times a year, on which 5 and 4 individuals of plants survived two years of the experiment (Table 2).

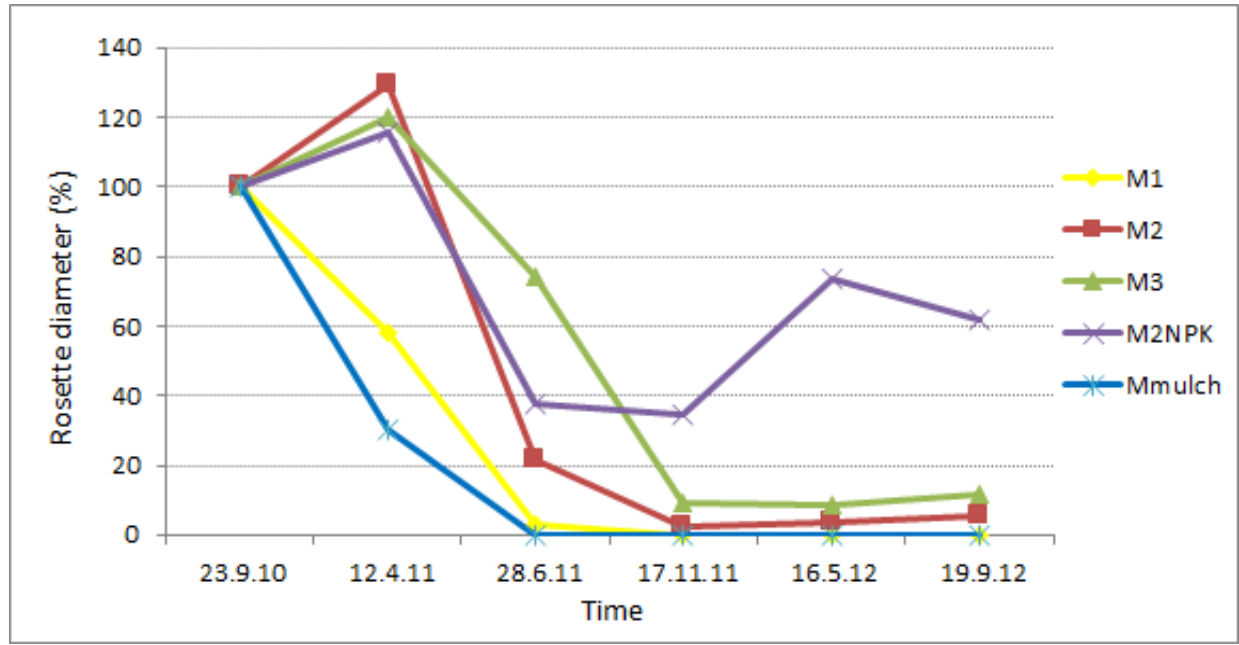

Fig. 2: Number of Sledner speedwell individuals in experimental mowing grassland. Marking of treatments corresponds with Figure 1. 


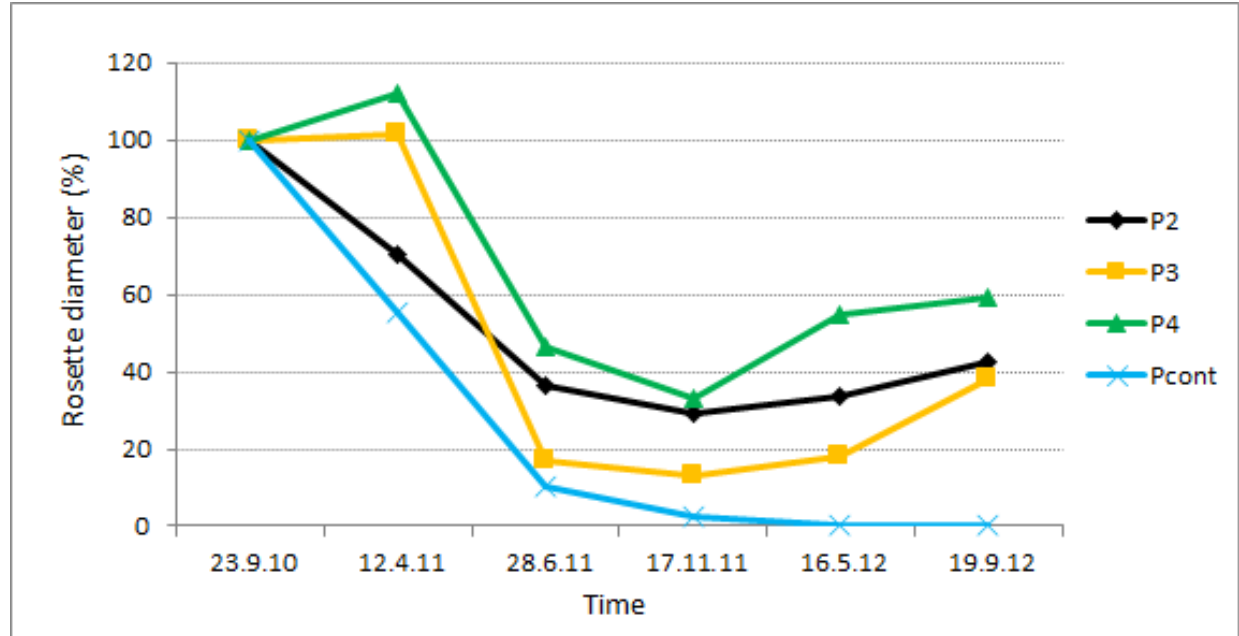

Fig. 3: Number of Sledner speedwell individuals in experimental grazing grassland. Marking of treatments corresponds with Figure 1.

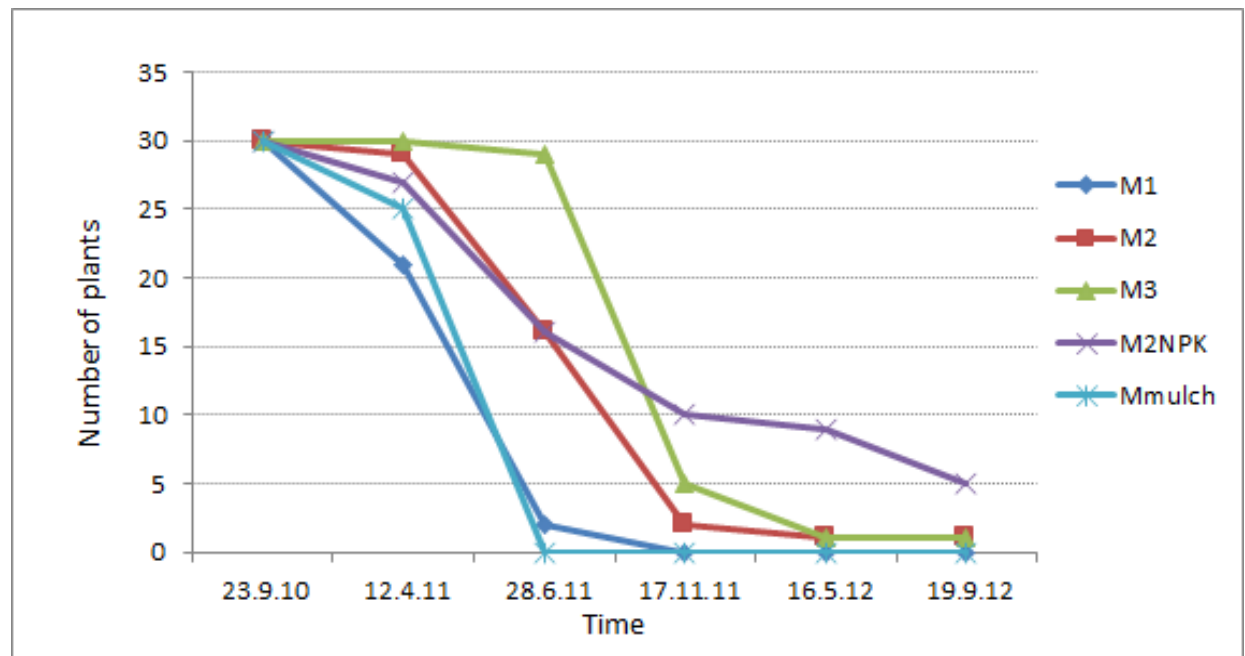

Fig. 4: Percentage of "rosette" diameter of Sledner speedwell in experimental mowing grassland. Marking of treatments corresponds with Figure 1.

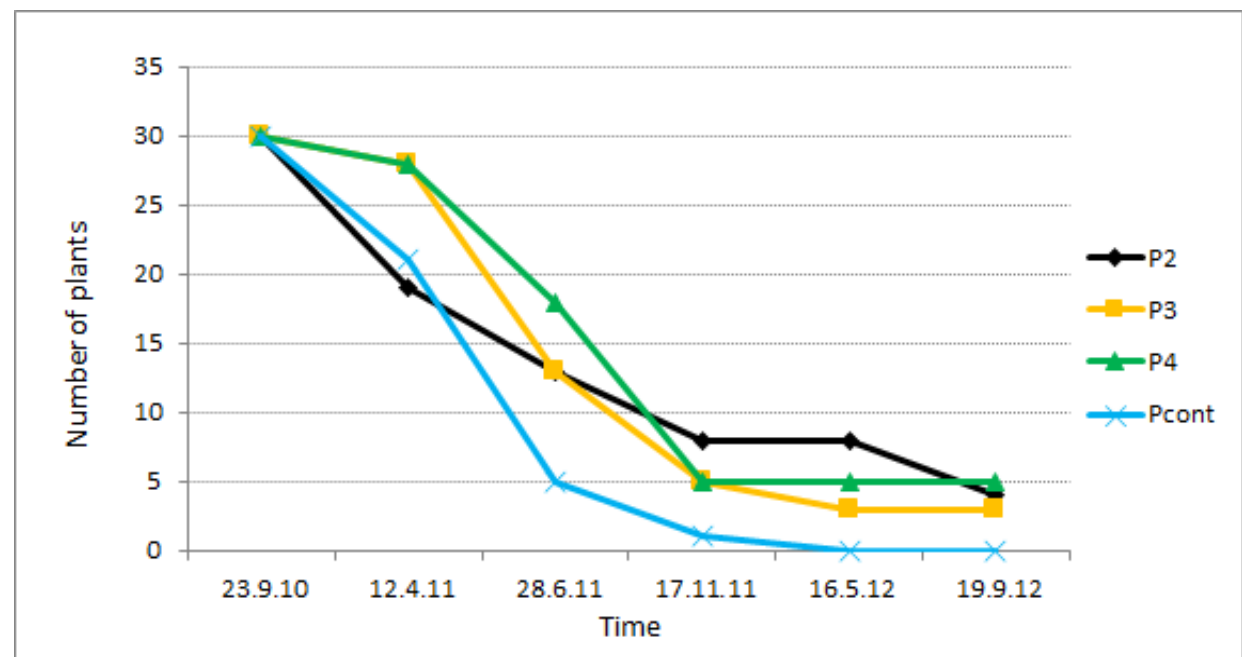

Fig. 5: Percentage of "rosette" diameter of Sledner speedwell in experimental grazing grassland. Marking of treatments corresponds with Figure 1. 


\section{DISCUSSION}

The experiment found that Slender speedwell was able to survive two winters on the lots, and for a short period of time also under certain grass cover managements. The ability of expansion was confirmed for some maternal plants (ŠERÁ 2012). The number and size of the plants depended on the particular management. A new finding of this experiment proves that Slender speedwell can prosper in grazed covers. For hilly regions, HEJCMAN et al. (2005) recommend grazing at least once a year, but in our experiment Slender speedwell better prospered in covers grazed 3 and 4 times a year, with a lower and more stable height.

Tab. 2: Characteristics of surviving plants of Slender speedwell in research lots with various management. Marking of treatments corresponds with Figure 1.

\begin{tabular}{|c|c|c|c|c|c|c|c|}
\hline \multirow{2}{*}{$\begin{array}{c}\text { Order of } \\
\text { plant }\end{array}$} & \multirow[t]{2}{*}{ Treatment } & \multicolumn{3}{|c|}{ Rossete diameter } & \multicolumn{3}{|c|}{ Number of peaks (1) } \\
\hline & & $\begin{array}{l}\text { Start of } \\
\text { experiment } \\
\text { (cm) }\end{array}$ & $\begin{array}{l}\text { Finish of } \\
\text { experiment } \\
(\mathrm{cm})\end{array}$ & $\begin{array}{l}\text { Finish of } \\
\text { experiment } \\
(\%)\end{array}$ & $\begin{array}{l}\text { Start of } \\
\text { experiment } \\
\text { (1) }\end{array}$ & $\begin{array}{l}\text { Finish of } \\
\text { experiment } \\
\text { (1) }\end{array}$ & $\begin{array}{l}\text { Finish of } \\
\text { experiment } \\
\text { (\%) }\end{array}$ \\
\hline 1 & M3 & 9 & 32 & 356 & 1 & 13 & 1300 \\
\hline 2 & M2 & 11 & 17 & 160 & 3 & 3 & 100 \\
\hline 3 & $\mathrm{M} 2_{\mathrm{NPK}}$ & 10 & 46 & 474 & 2 & 31 & 1550 \\
\hline 4 & $\mathrm{M} 2_{\mathrm{NPK}}$ & 6 & 37 & 587 & 1 & 10 & 1000 \\
\hline 5 & M2NPK & 9 & 38 & 427 & 3 & 23 & 767 \\
\hline 6 & $\mathrm{M} 2_{\mathrm{NPK}}$ & 11 & 25 & 238 & 1 & 12 & 1200 \\
\hline 7 & M2NPK & 13 & 18 & 135 & 3 & 9 & 300 \\
\hline 8 & G2 & 16 & 36 & 220 & 3 & 11 & 367 \\
\hline 9 & G2 & 11 & 24 & 212 & 2 & 7 & 350 \\
\hline 10 & G2 & 14 & 87 & 613 & 3 & 155 & 5167 \\
\hline 11 & G2 & 15 & 35 & 240 & 1 & 7 & 700 \\
\hline 12 & G3 & 11 & 34 & 298 & 2 & 8 & 400 \\
\hline 13 & G3 & 10 & 25 & 255 & 2 & 13 & 650 \\
\hline 14 & G3 & 11 & 67 & 588 & 2 & 131 & 6550 \\
\hline 15 & G4 & 10 & 5 & 51 & 1 & 2 & 200 \\
\hline 16 & G4 & 11 & 23 & 207 & 2 & 12 & 600 \\
\hline 17 & G4 & 10 & 102 & 1010 & 2 & 156 & 7800 \\
\hline 18 & G4 & 8 & 39 & 513 & 1 & 85 & 8500 \\
\hline
\end{tabular}

As was previously proved, Slender speedwell prospers in the vicinity of some dicotyledonous species (e.g. Lotus corniculatus) and it usually does not grow near monocotyledonous plants (eg. Agrostis tenuis, Dactylis glomerata, Festuca rubra, Lolium perenne) (ŠERÁ 2012). The presented experiment shows that Slender speedwell prospered better on grazed lots (except for permanent grazing) than on harvested covers. Within harvested covers, the most suitable were two-harvest lots with fertilizing (Figs. 2, 4). Dominant species on grazed lots were: Taraxacum sect. Ruderalia, Trifolium pratense, Plantago lanceolata, Cynosurus cristatus, Poa pratensis and Lolium perenne. Harvested lots, where Slender speedwell did not prosper $(1 \mathrm{x}$ harvested, $2 \mathrm{x}$ mulched) were dominated by wide-leaf grasses: Arrhenatherum elatius, Festuca pratensis and Holcus lanatus. These discussed the dominant plant species were taken from previous work (KOBES et al. 2013). 
Intensity of harvesting and removing phytomass reduces the number of grass species and supports dicotyledonous plants which are less competitive (KLAUDISOVÁ \& MUDRA 2004; ŠERÁ 2004). On pastures, speedwell can be supported when grazing animals step on the plant and press it to the soil (rooting possibility). Grazing animals might as well transport the creeper plants on short distances (plants fall out of their moths before they swallow them). The amount of above-ground biomass is more balanced on grazed covers during vegetation comparing to harvested covers, there are also fewer old plants and more grass species (HAZI et al. 2012; KOHLER et al. 2004), particularly in fertilized covers (LANTA et al. 2014).

A similar structure can be found in wetter, medium harvested or mulched grasslands on mildly wet soils, where Slender speedwell often propagates. "Leftovers" after grazing, particularly around solid excrements, providing big amounts of nitrogen (HEJCMAN et al. 2004), can also have a positive influence on the development of Slender speedwell.

It seems obvious that survival and growth of Slender speedwell is connected with the structure of the cover in terms of species, height and microclimate in the bottom layer of the cover (because of the delicate size of Slender speedwell). Slender speedwell seems to prosper better in medium high covers (see above) with enough light and humidity. Also changes in microclimatic conditions after harvesting the biomass are probably less distinct. Slender speedwell prospers better on localities rich in nutrients (see results about fertilizing and grazing). WEBER \& GUT (2004) describe the risk of non-indigenous species planted as ornamental plants and appearing recently on new locations. They are able to survive in more diverse conditions and covers, they are not categorized as weeds and killed with herbicides. Despite its low growth, Slender speedwell is in the risk category III, like Japanese knotweed or giant hogweed.

Survival and growth of plants might have been influenced by climatic conditions as well. Slender speedwell prospers better in colder and humid climate (HARRIS \& LOWELL 1980b). In 2011, the locality of Velký Chuchelec provided good conditions for the growth of Slender speedwell at the beginning of the vegetation period. Later that year, in August, after harvesting and removing the biomass, total rainfall was $50 \mathrm{~mm}$ (Table 1) and temperatures were above average. Grass localities were thus exposed to temporary dry conditions, which might have caused mortality or growth ceasing of the tested plats at summer and autumn evaluation (Figs. 2, 4).

Surviving plants were only on some lots and in low numbers (1-5 plants per a treatment, total number of plants 18). The spereading potencial of those plants was enormous, because average number of vegetative peaks per shoot was 38 and summary of the peaks was 688 (Table 2). Those plants were large and richly ramified, usually with adventitious roots and fertile blossoms (seed germination was not tested, but seeds were probably barren). There is an assumption that apexes are a source of vegetative propagation. Our experiment was run on harvested lots with immediate phytomass removal. Cut parts of Slender speedwell could not have been used. Such experiment brings results which are strictly applied to survival and growth possibilities of the planted individual. Aboveground parts of Slender speedwell regenerate best from apexes (ŠERÁ 2012), and can root more easily (in three days, SCALONE \& ALBACH 2012). Taking into account the fact that phytomass is usually left on commonly harvested meadows, invasive potential of Slender speedwell is relatively bigger.

Generally, mesophilic meadows are not largely invaded by neophytes, and have thus a relatively low invasibility (CHYTRÝ et al. 2008). Slender speedwell is an invasive species, naturalised in harvested grass covers (KAPLAN et al. 2016). The results of the presented experiment show that not only harvested meadows but also grazed pastures belong to possible biotopes of Slender speedwell. The presented results are of partial character, being a part of a more complex research which includes meadows of various altitudes. All acquired data are being processed and will be gradually published. 


\section{SUMMARY}

The presented data are results from an experimental location in Velky Chuchelec. The study confirms that Slender speedwell (Veronica filiformis) may grow fast in grassland with differend management. The best growth of plants was found in two-years mowed lots with fertilisation and in lots with cattle pasture crops (not permanent cattle grazing). Only small number of individuals survived at plots during two-years experiment, but the potential for the spreading of the species population is great.

\section{ACKNOWLEDGEMENTS}

This contribution is the result of the project implementation: SPECTRA+ No. 20240120002 "Centre of Excellence for the Development of Settlement Infrastructure of Knowledge Economy" supported by the ERDF and project "Science Park of Comenius University in Bratislava” ITMS 26240220086 supported by the ERDF.

\section{REFERENCES}

Chytrý M., Jarosik V., Pysek P., Hajek O., Knollova I., Tichy L. \& DAnihelKa J. 2008. Separating habitat invasibility by alien plants from the actual level of invasion. Ecology. 89: 1541-1553.

HARRIS G. R. \& Lovell P. H. 1980a. Adventious root formation in Veronica Spp. Ann. Bot. 45: 459-468.

HARRIS G. R. \& LOWELl P. H. 1980b. Localized spread of Veronica filiformis, Veronica agrestis and Veronica persica. Journal of applied ecology 17: 815-826. DOI: 10.2307/2402658.

Hazi J., Penksza K., Bartha S., Hufnagel L., Toth A., Gyuricza C. \& Szentes S. 2012. Cut mowing and grazing effects with grey cattle on plant species composition in case of pannon wet grasslands. Applied Ecology and Environmental Research. 10: 223-231.

Hejcman M., Auf D. \& Gaisler J. 2005. Year-round cattle grazing as an alternative management of hay meadows in the Giant Mts (Krkonose, Karkonosze), the Czech Republic. Ekologia-Bratislava. 24: 419-429.

Hejcman M., Pavlư V. \& Krahulec F. 2004. Pastva hospodářských zvírat. 7-14, In: Háková, A., Klaudisová A., Sádlo J.: Zásady péče o nelesní biotopy v rámci soustavy Natura 2000. Planeta XII, 3/2004 - druhá část. MŽP Praha, 144 p.

JEHLíK V. 1961. Rozšíření Veronica filiformis Smith v Československu a poznámky k jejímu výskytu. Preslia. 33: 315-321.

JEHLíK V. (ed.) 1998. Cizí expanzivní plevele České republiky a Slovenské republiky. Academia, Praha, 506 p.

JeHLíK V. \& Slavík B. 1967. Doplňky k rozšírení Veronica filiformis Smith v Československu. Preslia. 39: 206208.

Kaplan Z., Danihelka J., ŠtěPÁnKová J., Ekrt L., Chrtek J. JR., ZÁzvorka J., Grulich V., ŘePKA R., PRANČL J., DUChÁČEK M., KÚR P., ŠUMBEROVÁ K. \& BRŮNA J. 2016. Distributions of vascular plants in the Czech Republic. Part 2. Preslia. 88: 229-322.

Klaudisová A. \& Mudra S. 2004. Seč. 14-17, In: HákovÁ A., Klaudisová A., SÁdlo J.: Zásady péče o nelesní biotopy v rámci soustavy Natura 2000. Planeta XII, 3/2004 - druhá část. MŽP Praha, 144 p.

Kobes M., ŠERÁ B., NovotnÁ R. \& GAJdovÁ I. 2013. The influence of ecological conditions, management and stand boptanical composition on growth of slender speedwell (Veronica filiformis Smith) in grasslands. In: Aktuální témata v pícninářství a trávníkářství 2013. FAPPZ ČZU, Praha, 5. 12. 2013, pp. 85-97.

Kohler F., Gillet F., Gobat J.M. \& Buttler A. 2004. Seasonal vegetation changes in mountain pastures due to simulated effects of cattle grazing. Journal of Vegetation Science. 15: 143-150.

Lanta V., Dolezal J., Lantova P., KeliseK J. \& MudraK O. 2014. Effects of pasture management and fertilizer regimes on botanical changes in species-rich mountain calcareous grassland in Central Europe. Grass and Forage Science. 64: 443-453.

MülleR N. \& SUKOPP H. 1993. Synanthrope Ausbreitung und Vergesellschaftung des Fadenförmigen Ehrenpreises - Veronica filiformis Smith. Tuexenia. 13: 399-423. 
Pergl J., SÁdlo J., Petrusek A., Laštưvka Z., Musil J., Perglová I., ŠAnda R., Šefrová H., Šíma J., VOHRALÍK V., PYŠEK P. 2016. Black, Grey and Watch Lists of alien species in the Czech Republic based on environmental impacts and management strategy? NeoBiota. 28: 1-37.

PenIAŠTEKOVÁ M. \& ZLINSKÁ J. 1995. Veronica filiformis Sm. in Slovakia - notes on distribution, ecology and phytocoenology. Biológia Bratislava. 50: 13-18.

PYŠEK P. 2001. Past and future of predictions in plant invasions: a field test by time. Diversity and Distributions. 7: 145-151.

Pyšek P., Danihelka J., SÁdlo J., Chrtek J. JR., ChytrÝ M., JarošíK V., Kaplan Z., Krahulec F., Moravcová L., Pergl J., Štajerová K. \& TichÝ L. 2012. Catalogue of alien plants of the Czech Republic (2nd edition): checklist update, taxonomic diversity and invasion patterns. Preslia. 84: 155-255.

SCAlone R. \& Albach D. C. 2012. Degradation of sexual reproduction in Veronica filiformis after introduction to Europe. BMC Evolutionary Biology. 12: a.n. 233. DOI: 10.1186/1471-2148-12-233.

SOJÁK J. \& ŠOUREK J. 1959. Veronica filiformis Sm. v Československu. Preslia. 31: 421-424.

ŠERÁ B. 2004. T1 Louky a pastviny. 93-107, In: HÁKOVÁ A., KLAudisovÁ A., SÁdLO J.: Zásady péče o nelesní biotopy v rámci soustavy Natura 2000. Planeta XII, 3/2004 - druhá část. MŽP, Praha, 144 p.

ŠERÁ B. 2012. Which stem parts of Slender speedwell (Veronica filiformis) are the most successful in plant regeneration? Biológia Bratislava. 67: 110-115.

USDA, NRCS 2016. The Plants Database. - United States Department of Agriculture. URL: http://plants.usda.gov (20. 9. 2016).

Webb C. J., Sykes W. R. \& Garnock-Jones P. J. 1988. Flora of New Zealand. Vol. 4. Naturalised pteridophytes, gymnosperm and dicotyledons. Christchurch, New Zealand, 1365 p.

WEBER E. \& GUT D. 2004. Assessing the risk of potentially invasive plant species in central Europe. Journal of Nature Conservation. 12: 171-179. 